\title{
In vitro Antimalarial Activity of 11 Terpenes Isolated from Ocimum gratissimum and Cassia alata Leaves. Screening of Their Binding Affinity with Haemin
}

\author{
Kayembe J. S. ${ }^{1}$, Taba K. M. ${ }^{1}$, Ntumba K. ${ }^{1}$ \& Kazadi T. K. ${ }^{1}$ \\ ${ }^{1}$ Department of Chemistry, Faculty of Sciences, University of Kinshasa, Democratic Republic of Congo \\ Correspondence: Kayembe J. S., Department of Chemistry, University of Kinshasa, Democratic Republic of \\ Congo. E-mail: jeanksm@unikin.cd
}

Received: January 16, 2012 Accepted: February 13, 2012 Online Published: August 21, 2012

doi:10.5539/jps.v1n2p168

URL: http://dx.doi.org/10.5539/jps.v1n2p168

\begin{abstract}
Eleven terpenes extracted from Cassia alata and Ocimum gratissimum leaves were screened for in vitro antimalarial activity against Plasmodium falciparum and for their binding affinity with haemin in ethylene Glycol-water 3:7 solvent. Nine terpenes have promising antimalarial activity with $\mathrm{IC}_{50}$ values below $1 \mu \mathrm{g} / \mathrm{ml}$; two terpenes showed a good activity with $\mathrm{IC}_{50}$ values below $4 \mu \mathrm{g} / \mathrm{ml}$. All the terpenes bind strongly with haemin as shown by variation of absorbance of the haemin at $\lambda 600 \mathrm{~nm}$ in UV-Visible spectrum.
\end{abstract}

Keywords: Cassia alata, Ocimum gratissimum, antimalarial activity, terpenes, binding affinity, haemin

\section{Introduction}

Many studies have been reported on the in vitro antimalarial activity of terpenes (Kalauni et al., 2006; Suksarman et al., 2006; Chukwejeku et al., 2005), on biological activities of Ocimum gratissimum essential oil (Ueda-Nakamura et al., 2006; Tchoumbougnang et al., 2005; Usip et al., 2006) and on antimicrobial activity of aqueous and ethanol extracts of Cassia alata (Somchit et al., 2003; Villasenor et al., 2002; Ranganathan et al., 2000).

In addition, the main antimalarial mode of action of quinolines (Chou et al., 1980; David \& Sullivan, 2002; Sugioka et al., 1987) and artemisinin derivatives whose structures are totally different with those of quinoline alkaloids (Kamnan et al., 2002; Krishna et al., 2004; Meshnick, 2002) has been established to be their inhibition of haemin polymerisation through their binding with haemin.

In the present work, we aim to evaluate in vitro the antimalarial activities of eleven terpenes isolated from Cassia alata (four) and Ocimum gratissimum (seven) given that terpenes are easily extractible and these leaves contain high levels of terpenes.

We carried out also qualitative studies of their binding affinity with haemin in order to get first knowledge of their mode of action; because the detection of haemin-binding properties of molecules could be used as a preliminary test for antimalarial activity (Steel et al., 2002).

\section{Materials and Methods}

\subsection{Plant Materials}

Plants were collected in Kinshasa/ Kisenso, DR Congo and were authenticated by the Herbarium service of Department of Biology, University of Kinshasa where voucher specimens are preserved. The leaves were air dried at room temperature for 20 days and then grinded with pestle and mortar.

\subsection{Extraction of Terpenes}

Extraction of terpenes was carried out according to the general procedure described by Bruneton (Bruneton, 1993). The dried and grinded leaves $(200 \mathrm{~g})$ were macerated during 7 days in $\mathrm{CH}_{2} \mathrm{Cl}_{2}(2 \times 2.51)$ at room temperature. $\mathrm{CH}_{2} \mathrm{Cl}_{2}$ extract was suspended in EtOH- $\mathrm{H}_{2} \mathrm{O}$ 3:7 mixture and then extracted with Petroleum ether $\left(60-80^{\circ} \mathrm{C}\right)$ to afford fraction $\mathrm{A}$ after concentration under reduced pressure. $\mathrm{EtOH}-\mathrm{H}_{2} \mathrm{O}$ fraction was subjected to evaporation under reduced pressure to give a residue which was then dissolved in $\mathrm{MeOH}$. The fraction $\mathrm{B}$ was obtained after evaporating $\mathrm{MeOH}$. Fractions $\mathrm{A}$ and $\mathrm{B}$ were combined to give the terpenes extracts which were 
separated by preparative TLC on precoated silica gel 60F254 plates (Merck) using EtOAc-Petroleum ether 4:1. Four terpenes (TCA1-TCA4) were isolated from Cassia alata and seven (TOG1-TOG7) from Ocimum gratissimum. Individual terpen was rechromatographied on silica gel column using the same solvent system. All isolated compound had a positive response to the Liebermann test (concentrated $\mathrm{H}_{2} \mathrm{SO}_{4}$ in mixture with acetic anhydride).

\subsection{Antimalarial Activity}

The in vitro assays were conducted by using the micro dilution technique of Desjardin (Desjardin et al., 1979). The P. falciparum parasites were derived by direct visualization and micro manipulation from fresh patient isolates. The test compounds were initially dissolved in $\mathrm{EtOH}: \mathrm{H}_{2} \mathrm{O}$ mixture $(1: 3)$ or in DMSO and diluted 100-fold in RPMI 1640 culture medium, supplemented with $25 \mathrm{mM}$ Hepes and $32 \mathrm{mM} \mathrm{NaHCO}_{3}$. These solutions were diluted in 10 different concentrations. The parasites were exposed to different dilutions of each compound for $48 \mathrm{~h}$ and incubated at $37^{\circ} \mathrm{C}$. Direct estimation of parasite growth inhibition was used and it was based on direct reading of smears made in 24-well, flat-bottomed plates to estimate growth and evolution stages of the parasites (Bemoit et al., 1996).

Parasitaemia and parasite stage were determined after $48 \mathrm{~h}$ of contact between extracts and parasites. Concentration-response data were analyzed by nonlinear regression logistic dose-response model and $\mathrm{IC}_{50}$ values for each compound were calculated.

\subsection{Binding Affinity with Haemin}

Propylene glycol- $\mathrm{H}_{2} \mathrm{O}$ 3:7 was used as solvent for the study of binding affinity of all terpenes with haemin, owing to the fact that haemin forms dimers in aqueous media at $\mathrm{pH}<9$. In all experiments $\mathrm{pH}$ and haemin concentrations were maintained constant $\left(\mathrm{pH} 10.75 ; 0.310^{-5}=2 \mu \mathrm{g} / \mathrm{ml}\right)$. Under these conditions, haemin exists only in monomeric form. UV - Visible spectra of haemin were recorded between 420 and $700 \mathrm{~nm}$ using ZUZI ${ }^{\circledR}$ UV - 4200 spectrophotometer in presence of increasing concentrations of terpenes $(0.02$ to $2 \mathrm{mg} / \mathrm{ml})$. A decrease of haemin absorbance at its $\lambda \max (600 \mathrm{~nm})$ indicates binding affinity of terpen with haemin. The binding affinity was estimated as the absorbance difference between haemin solution and haemin solution in presence of the highest concentration of terpen $(2 \mathrm{mg} / \mathrm{ml})$.

\section{Results and Discussion}

The results of the antimalarial activities of isolated terpenes (Table 1) show that the 4 terpenes from Cassia alata (TCA1 - TCQ4) and 5 from Ocimum gratissimum (TOG1, TOG2, TOG5, TOG6 and TOG7) are the very active against Plasmodium with all their $\mathrm{IC}_{50}$ below $1 \mu \mathrm{g} / \mathrm{ml}$. TOG3 and TOG4 are active with $\mathrm{IC}_{50}$ values $<4 \mu \mathrm{g} / \mathrm{ml}$. The unceasingly crescent interest of terpenes is due to their high antimalarial activities. The $\mathrm{IC}_{50}$ values recorded for many of them are around 0.1 to $3.5 \mu \mathrm{g} / \mathrm{ml}$ (Kalauni et al., 2006; Suksarman et al., 2006; Chukwejeku et al., 2005; Jullian et al., 2005; Ma et al., 2005).

Table 1. Antimalarial activity of isolated terpenes

\begin{tabular}{llll}
\hline Plant & Terpene & $\mathrm{Rf}$ & $\mathrm{IC}_{50}(\mu \mathrm{g} / \mathrm{ml})$ \\
\hline Cassia alata & TCA1 & 0.35 & 0.94 \\
Cassia alata & TCA2 & 0.48 & 0.23 \\
Cassia alata & TCA3 & 0.55 & 0.44 \\
Cassia alata & TCA4 & 0.65 & 0.52 \\
Ocimum gratissimum & TOG1 & 0.06 & 0.32 \\
Ocimum gratissimum & TOG2 & 0.14 & 0.27 \\
Ocimum gratissimum & TOG3 & 0.21 & 1.41 \\
Ocimum gratissimum & TOG4 & 0.37 & 3.96 \\
Ocimum gratissimum & TOG5 & 0.47 & 0.44 \\
Ocimum gratissimum & TOG6 & 0.59 & 0.65 \\
Ocimum gratissimum & TOG7 & 0.87 & 0.52 \\
Quinine & & & 0.1 \\
\hline
\end{tabular}

In addition, terpenes are major components of essential oils which have various therapeutic virtues, justifying their use in traditional medicine. The main constituents of Ocimum gratissimum essential oil Eugenol, 
phellandrene, thymol, limonene (Ueda-Nakamura et al., 2006; Tchoumbougang et al., 2005) are known to possess many biological activities (Lahlou et al., 2004; Interaminense et al., 2005; Usip et al., 2006). Cassia alata is used in traditional medicine in various regions of the world; its inhibition activity on the growth of larvae of Chrysoma megacephala has been reported (Kumarasinghe et al., 2002). To our knowledge, this study is the first to report an antimalarial activity of the terpenic fraction of Cassia alata.

The results mentioned in Table 2 show that all terpenes studied have a binding affinity with the haemin characterized by a diminution of haemin absorbance at the $\lambda \max (600 \mathrm{~nm})$ when terpenes concentration increases (Figures 1 and 2).

Table 2. Biding affinity of isolated terpenes with haemin

\begin{tabular}{lll}
\hline Terpene & Rf & Biding affinity $\Delta \mathrm{A}$ \\
\hline TCA1 & 0.35 & 0.089 \\
TCQ2 & 0.48 & 0.115 \\
TCA3 & 0.55 & 0.104 \\
TCA4 & 0.65 & 0.091 \\
TOG1 & 0.06 & 0.089 \\
TOG2 & 0.14 & 0.092 \\
TOG3 & 0.21 & 0.076 \\
TOG4 & 0.37 & 0.079 \\
TOG5 & 0.47 & 0.087 \\
TOG6 & 0.59 & 0.080 \\
TOG7 & 0.87 & 0.080 \\
\hline
\end{tabular}

$\Delta \mathrm{A}=\mathrm{AH}-\mathrm{AH}+\mathrm{T}$ with $\mathrm{AH}=$ haemin solution absorbance; $\mathrm{AH}+\mathrm{T}=$ haemin + highest concentration of terpene solution absorbance.

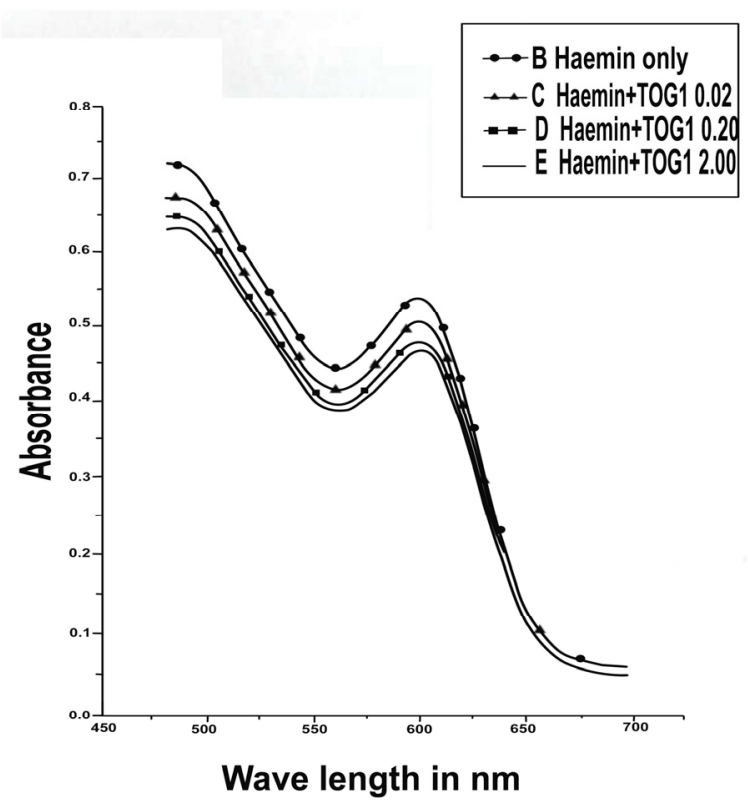

Figure 1. Haemin spectrum in presence of increasing concentrations of TOG1

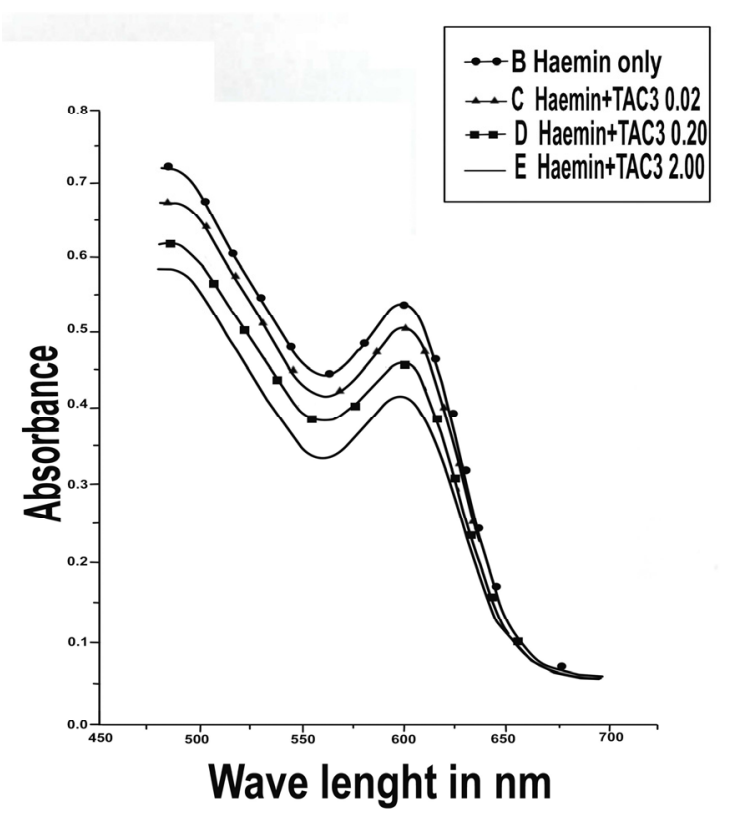

Figure 2. Haemin spectrum in presence of increasing concentrations of TCA3

This interaction with haemin could explain the high antipaludic activity recorded for this class of compounds. Indeed, Chauhan et al. (2002) have shown that a terpene like artemisinin inhibits the haemin polymerization in 
hemozoin through its ability to form complexes with haemin. Paitayatat et al. (1997) have correlated antimalarial activity of artemisinin derivatives with their binding affinity with ferriprotoporphyrin IX (haemin). The fall in haemin absorbance at $600 \mathrm{~nm}$ is due to the interaction between porphyrin core of haemin and antimalarial compound. Because, an interaction by charge transfer which could take place between the central iron atom and the antimalarial could have been observed on UV part of haemin spectrum. So, the detection of haemin-binding properties of molecules could be used as a preliminary test for antimalarial activity (Steel et al., 2002).

\section{Conclusion}

Terpenes from Cassia alata and Ocimum gratissimum are very active compounds in malaria treatment. The qualitative studies of their binding affinity with haemin point to fact that they act on Plasmodiums through a binding with haemin.

Further investigations required determination of the structures of isolated compounds and quantitative studies of their binding affinity to haemin in order to determine they complexes formation constants.

\section{References}

Benoît, F., Valentin, A., Pelissier, Y., Diafouka, C., Marion, C., Kone-Bamba, D., ... Bastide, J. M. (1996). In vitro antimalarial activity of vegetal extracts used in West African Traditional Medicine. Am J Trop Med Hyg, 54(1), 67-71.

Bruneton, J. (1993). Pharmacognosie, Phytochimie; Plantes Médicinales. (2nd ed.). Tec \& Doc. Lavoisier Paris pp. 623-642.

Chou, A. C., Chevli, R., \& Fitch, C. D. (1980). Ferriprotoporphyrin IX fulfills the criteria for Identification as the Chloroquine receptor of Malaria Parasites. Biochem, 19, 1543-1549. http://dx.doi.org/10.1021/bi00549a600

Chukwujeku, J. C., Smith, P., Coombes, P. H., Mulholland, D. A., \& Vanstaden, J. (2005). Antiplasmodial Diterpenoid from the leaves of Hyptis suaveolens. J. Ethnopharmacol, 102(2), 295-297. http://dx.doi.org/10.1016/j.jep.2005.08.018

Interaminense, L. F., Leal, J. H., Caldas, M. P. J., Pinto, D. G., \& Laulou, S. (2005). Enhanced Hypotensive effects of the essential oil of Ocimum gratissimum leaves and its main constituent, eugenol, in DOCA-salt hypertensive conscious rats. Planta Med, 71(4), 376-378. http://dx.doi.org/10.1055/s-2005-864109

Jullian, V., et al. (2005). New clerodane diterpenoids from Laetitia procera (Poepp.) Eichler (Flacourtiaceae), with antiplasmodial and antileishmanial activities. Bioorg Med Chem Lett, 15(22), 5065-5070. http://dx.doi.org/10.1016/j.bmcl.2005.07.090

Kalauni, S. K., Suresh, A., Yasuhiro, T., Arjun, H. B., Thein, Z. L., Puji, B. S. A., ... Shigetoshi, K. (2006). Antimalarial activity of cassane- and norcassane-type diterpenes from Caesalpinia crista and their structure-activity relationship. Biol Pharm Bull, 29(5), 1050-1052. http://dx.doi.org/10.1248/bpb.29.1050

Kamnan, R., Scheha, D., \& Chauhan, V. S. (2002). Heme-Artemisinin Adducts are crucial Mediators for the ability of Artemisinin to inhibit heme polymerisation. Chem. And Biol, 9(3), 321-332. http://dx.doi.org/10.1016/S1074-5521(02)00117-5

Krishna, S., Uhlemann, A. C., \& Haynes, R. K. (2004). Artemisinin: mechanism of action and potential Resistance. Drug Resist. Updates, 7(4-5), 233-244. http://dx.doi.org/10.1016/j.drup.2004.07.001

Kumarasinghe, S. P., Nadira, D. K., Ranjan, L. L., Lakshmi, S. R., \& Roshinie, D. S. C. (2002). Larvicidal effects of mineral turpentine, low aromatic white spirits, aqueous extracts of Cassia alata, and aqueous extracts, ethanolic extracts and essential oil of betel leaf (Piper betle) on Chrysomya megacephala. In.t J. Dermatol, 4l(12), 877-880. http://dx.doi.org/10.1046/j.1365-4362.2002.01660.x

Lahlou, S., Leylliane, F. L., Jose, H. L. C., Selene, M. M., \& Gloria, P. D. (2004). A cardiovascular effect of the essential oil of Ocimum gratissimum leaves in rats: role of the autonomic nervous system. Clin Exp Pharmacol Physiol., 31(4), 219-225. http://dx.doi.org/10.1111/j.1440-1681.2004.03976.x

Ma, C., Zhang, H. J., Tan, G. T., Hung, N. V., Cuong, N. M., Soejarto, D. D., ... Fong, H. H. S. (2006). Antimalarial compounds from Grewia bilamellata. $J$ Nat Prod, 69(3), 346-350. http://dx.doi.org/10.1021/np050313d

Meshnick, S. R. (2002). Artemisinin: mechanism of action, resistance and toxicity. Intern. J. Parasitol, 32(13), 1655-1660. http://dx.doi.org/10.1016/S0020-7519(02)00194-7 
Ranganathan, S., \& Balajee, S. A. (2000). Anti-Cryptococcus activity of combination of extracts of Cassia alata and Ocimum sanctum. Mycoses, 43(7-8), 299-301. http://dx.doi.org/10.1046/j.1439-0507.2000.00581.x

Somchit, M. N., Reezal, I., Elysha, N. U. R., \& Mutalib, A. R. (2003). In vitro antimicrobial activity of ethanol and water extracts of Cassia alata. $J$ Ethnopharmacol, 84(1), 1-4. http://dx.doi.org/10.1016/S0378-8741(02)00146-0

Sugiokia, Y., Suzuki, M., Sugioka, K., \& Nakano, M. (1987). A Ferriprotoporphyrin IX - Chloroquine Complex Promotes membrane Phospholipids peroxidation. A possible mechanism for Antimalarial action. FEBS letters, 223(2), 251-254. http://dx.doi.org/10.1016/0014-5793(87)80299-5

Suksamrarn, S. (2006). Ceanothane- and lupane-type triterpenes with antiplasmodial and antimycobacterial Ceanothane- and lupane-type triterpenes with antiplasmodial and antimycobacterial activities from Ziziphus cambodiana. Chem Pharm Bull (Tokyo), 54(4), 535-537. http://dx.doi.org/10.1248/cpb.54.53

Sullivan, D. J., Gluzman, L. Y. Jr., \& Bolberg, D. E. (1996). Plasmodium Hemozoin Formation mediated by Histidin -Rich Proteins. Sciences, 271, 219 -221. http://dx.doi.org/10.1126/science.271.5246.219

Tchoumbougnang, F., Amvam, Z. P. H., Dagne, E., \& Mekonnen, Y. (2005). In vivo antimalarial activity of Essential oils from Cymbopogon citratus and Ocimum gratissimum on mice infected with Plasmodium berghei. Planta Med, 71(1), 20-23. http://dx.doi.org/10.1055/s-2005-837745

Ueda-Nakamura, T., Ricardo, R. M. F., Jose, A. M., Paloma, K. M., Benedito, P. D. F., Diogenes, A. G. C., ... Celso, V. N. (2006). Antileishmanial activity of Eugenol-rich essential oil from Ocimum gratissimum. Parasitol Int, 55(2), 99-105. http://dx.doi.org/10.1016/j.parint.2005.10.006

Usip, L. P., Opara, K. N., Ibanga, E. S., \& Atting, I. A. (2006). Longitudinal evaluation of repellent activity of Ocimum gratissimum (Labiatae) volatile oil against Simulium damnosum. Mem. Inst Oswaldo Cruz, 101(2), 201-205. http://dx.doi.org/10.1590/S0074-02762006000200012

Villasenor, I. M, Canlas, A. P., Pascua, M. P., Sabando, M. N., \& Soliven, L. A. P. (2002). Bioactivity studies on Cassia alata Linn. Leaf extracts. Phytother Res, 16(Suppl 1), 893-896. http://dx.doi.org/10.1002/ptr.768 